\title{
COVID-19 Pandemic Impact on the Exports and Imports
}

\author{
Mihaela Gabriela Belu ${ }^{1}$
}

\begin{abstract}
This paper's objectives are the following: describing the impact of the COVID 19 crisis on the mechanism of export-import operations; the evolution of Romania's export-import activities during 2020-2021 and identifying some recommendations meant to belp companies fight the sanitary crisis' effects. The study is based on a theoretical research investigating the impact of the sanitary crisis on the management of an export-import operation. Due to disruptions in global supply chains, the companies operating in the field of international trade had to redefine their operating strategies for the foreign markets. The magnitude of these changes related to the transactional mechanism specific to export-import activities will lead to profound mutations in the global supply chain, with benefits in term of resilience in all phases of the supply chain.
\end{abstract}

Keywords: COVID-19, exports, imports, supply chain

JEL classification: F31, F1, O33

DOI: $10.24818 / \mathrm{REJ} / 2021 / 82 / 03$

\section{Introduction}

The COVID-19 pandemic has generated an unprecedented global shock, with devastating effects on international trade. The pandemic has been described as being: "a global shock 'like no other' and characterized by simultaneous supply and demand disruptions in an interconnected world economy" (Chudik et al., 2020). The impact of the pandemic on international trade was manifested by the disruption of activities at the level of the global value chain with a major impact on the activity of companies: gaps in the process of supply of raw materials/semi-finished products/components; problems in the production process: interruptions, late delivery of products; issues related to the marketing of products, mainly caused by syncope in the organization of logistics activities (transport, customs clearance, etc.).

1 The International Business and Economics Department, The Bucharest University of Economic
Studies, Bucharest, Romania, e-mail:belumihaela@gmail..com, orcid.org/0000-0001-7631-6798

Year XXIV no. 82

December 2021 
The effects of the COVID crisis on global trade were felt differently in relation to the two components: trade in goods and trade in services. In the field of services, there was a decrease by $20 \%$ in 2020 , and the trade in goods decreased by $8.9 \%$, the biggest decrease recorded since 2009. For 2021, WTO estimated an increase in global trade by 10.8\% (Dickinson, R., Zemaityte, G. 2021).

The purpose of this paper is to identify the changes that occurred during the COVID-19 pandemic, in terms of: establishing business relationships, negotiating and contracting international trade and the performance of the international salepurchase contract; to quantify the impact of the crisis on the trade flows carried out by Romanian companies with foreign trading partners; to identify the measures taken by companies in order to reduce the negative impact on exportimport transactions.

The paper is structured as follows: the first part is intended to review the relevant literature on the specifics, stages and the manner in which the export-import operations are being carried out; the next part presents the impact of the health crisis on the management of export-import transactions, and the case study analyses the effects of COVID-19 on Romanian foreign trade. The paper ends with a series of recommendations and conclusions.

\section{Export-import process overview}

Export-import operations are ways to enter foreign markets, along with strategic alliances/international cooperation and implantation abroad. Export and import are part of the value chain, respectively the supply-sales chain. The export operation is closely related to the symmetrical import operation, respectively the purchase of goods - goods and services - from abroad. In some cases, the import is a premise for export operations; for example, when goods are supplied from abroad for the purpose of producing goods for export (Popa and Belu 2018)

The export-import operations are characterized by the following features: (a) the complex nature of foreign trade transactions results from the fact that it involves upstream (intermediation operations in foreign trade, representation/commission, respectively agency) and downstream (packaging, shipping, transportation, storage, insurance, payment and financing) operations related to the actual export-import relationship; (b) the impact of internationalization and intercultural elements: the export-import operations are carried out between partners from different countries, affected by trade policy measures and administrative regulations targeting the external sector of the economy. The differences related to the political system, the legislative framework, the policy promoted in the field of 
foreign economic relations are directly reflected on the process of international contracting and performance. On the other hand, national or regional cultural differences express different approaches in terms of values and requirements of social existence and development, behavior and communication, the relationship between legal and ethical, etc., with a major impact on the business world. Specialized studies reveal differences in terms of cultural dimensions such as: hierarchy vs. social equality, individualism vs. collectivism, conflicting values vs. cooperative values, assumption vs. risk avoidance, introverted orientation vs. extroverted orientation (Popa, 2006); (c) a series of specific risks appear, especially those of the circumstantial type, respectively the price risk, the currency risk and the interest rate risk. This imposes the use of means of protection against risk, which can be of two types: contractual methods (adaptation and renegotiation clauses, respectively) and non-contractual methods (hedging with futures and options); (d) the participants: foreign trade transactions are carried out between economic operators from different countries. These are either public bodies (for example, state agencies or institutions, representing forms of performance of the economic function of the state), or, in particular, private companies, set up in various forms according to the laws of the countries where their registered offices are located (joint stock companies, limited liability, etc., or, from another perspective, publicly set up companies, named and open, respectively privately set up companies, closed). Transnational companies/corporations have a special role in international trade, as they are usually involved in export-import operations through their trade subsidiaries, or through various forms of strategic alliances and cooperation (joint ventures).

Carrying out an export operation involves going through several stages, from the export decision, to researching foreign markets, negotiating, contracting and executing the international sales contract (see figure below).

Figure 1. Stages of exporting

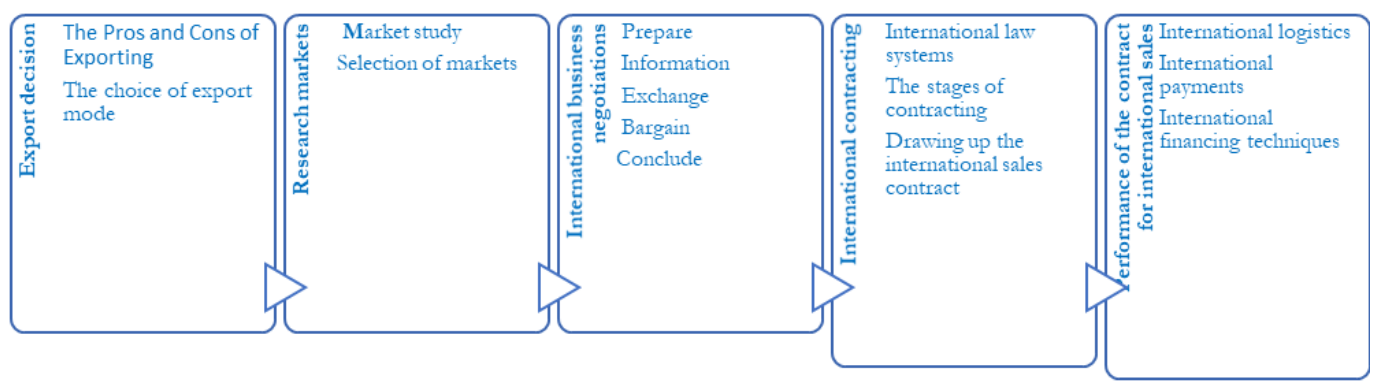

Source: Belu, M. (2017) 
Export-import operations, through their specific mechanism of development, involve the participation of a large number of participants, carrying out activities in the field of marketing, negotiation, contracting, logistics, financial-banking. The important role of the documents specific to an export-import operation (commercial documents, transport documents, customs documents, insurance documents) should be mentioned; based on the documents, the exporter requests the collection of the value of delivered goods and the importer, based on the original bill of lading in particular, takes possession of the goods arrived at the destination. International trade negotiation and contracting are stages that, in case of success, result in the conclusion of the international sale-purchase contract. Based on the content of the contract, during the performance stage of the contract, the two contracting parties, the exporter and the importer have to perform a series of logistical or financial-banking activities aimed at fulfilling the contractual obligations and, therefore, the performance of the contract in good conditions.

Export-import operations, through the specific mechanism of development, involve the participation of a large number of participants, carrying out activities in the field of marketing, negotiation, contracting, logistics, financial-banking. It should be mentioned the important role of documents specific to an exportimport operation (commercial documents, transport documents, customs documents, insurance documents); on the basis of the documents, the exporter requests the collection of the value of the goods delivered and the importer, on the basis of the documents, in particular the original bill of lading, takes possession of the goods arrived at the destination. International trade negotiation and contracting are stages that have, in case of success, resulted in the completion of the international sale-purchase contract. Starting from the content of the contract, the two contracting parties, the exporter and the importer, in the execution phase of the contract, have to perform a series of logistical or financialbanking activities aimed at fulfilling the contractual obligations and therefore the execution of the contract in good conditions

\section{The impact of the COVID-19 crisis on exporting and importing}

The COVID-19 crisis led to changes related to the manner in which the activities specific to export-import operations are carried out, namely: export decision, market prospecting, establishing business relationships, negotiating and contracting, the manner in which the contract specific to export-import transactions is carried out/executed. 
The first stage, the export decision, involves balancing the pros and cons of starting the trade operations. Amongst the pro arguments for export decision, we can mention: the turnover increase, the diversification of the client portfolio, reducing the risks through the diversification of the markets. Amongst the cons, we mention: the costs specific to the initiation and conduct of the export operation, the specific risks (e.g. the price risk, the currency risk), the impact of cultural and legislative differences amongst business partners. Once the export decision is made, the manufacturing company opts for the export method (direct export, indirect export, export through intermediaries).

Regarding the research activity of the foreign markets following which the export/import markets are selected (market accessibility is taken into account: physical, commercial, cultural accessibility), as well as the establishment of business relationships in order to initiate negotiations, the companies conducting trade activities abroad have adapted their marketing strategy to the existing conditions. Digital prospecting is increasingly used, having advantages such as: the financial resources needed to prepare and carry out this type of prospecting are more reduced as compared to the classic prospecting method, and the assessment of the prospecting activity's performance is easy to do.

In 2020-2021, the commercial events took place, mainly, in the virtual environment. Virtual fairs and exhibitions are events organized in an online environment that allow participants to provide information about the products/services they sell. Such a trade event involves lower costs for both exhibitors and visitors, being an accessible tool during the health crisis. The fair and exhibition industry was severely affected by the health crisis, and many trade events being cancelled or rescheduled. During this period, online fairs, exhibitions and other trade events were useful tools for establishing business relationships.

International trade negotiation allows the parties to reach an agreement, by going through the specific stages of this process, namely: preparing for negotiations (identify all issues, set priorities, establishing the negotiation strategy, etc.), opening session (initial offers, posturing), bargain and problem-solve (arguments and objections, concessions and compromises) and conclude of negotiations.

Recently, a lot of negotiations took place in the online environment, given that, before the health crisis, an increasing number of dealmakers were connected through digital tools (Shonk, K. 2020). Video technologies, teleconferencing and the e-mail have become effective ways for teams to prepare and negotiate with future business partners (Movius, H. 2020). 
The main result of international commercial contracting is the drafting of the international sales contract, the legal basis of the export operation. At this stage in the contracting process, business partners need to take into account the differences between the legal systems (civil law, common law, Islamic law and Far Eastern law). The methods of commercial contracting are: contracting by negotiation, contracting by correspondence and electronic contracting. Commercial contracting has been influenced by the measures taken during the health crisis. Due to the restrictions imposed by the pandemic, the preferred method of contracting was contracting between absentees. In the current context, during the contracting process, the trading partners pay more attention to the contractual clauses meant to manage the risks of non-performance of the contract, circumstantial risks, etc. (Shih, W.C. 2020). Increased attention is paid to the force majeure clause: in case the performance of the contract becomes temporarily or definitively impossible, the force majeure clause may be invoked. Also, if, due to unpredicted events, the performance of a contract becomes excessively onerous for one of the parties, this may, under certain conditions, rely on another exception to the principle of binding force of contracts, unpredictability. Force majeure usually refers to situations such as extreme weather events, riots, war, terrorist attacks or invasion, government or regulatory action, famine, epidemics and/or the imposition of an embargo. Although it is less common to see force majeure clauses that expressly include a global health emergency, a pandemic or epidemic, we appreciate that, under certain conditions, such events - as the health crisis - may also fall within the scope of a force majeure clause.

The current context in which international trade transactions take place calls for a more relaxed approach in assessing the causes of exemption from performance of obligations, even temporarily, precisely in order to ensure a decent level of stability in contractual relationships.

Thus, the COVID-19 epidemic may be a case of force majeure, if it meets the conditions provided by law: (i) the event is certainly not related to the will of the parties; (ii) unpredictability must be analysed in relation to the specific case, and thus, although it could be argued that the COVID-19 threat has appeared in December last year, the reality is that the local market is only beginning to feel the actual effects of the pandemic; (iii) the condition that the pandemic is unavoidable is to be re-examined on a case-by-case basis, the parties having to carry out a concrete analysis of the triggering event and of the causal connection between the event and the obligation to be enforced.

If an event (or series of events) triggers a force majeure clause, the party invoking the clause may suspend, postpone or be released from its contractual obligations 
without being liable. In order for it to operate, though, it is not enough for the party to invoke that clause. First, the interested party will have to verify the language used in the contract, especially in the case of contracts for which the force majeure clause has been negotiated and limited.

Next, an analysis must be carried out, with regard to the fulfilment of the conditions mentioned above (although there are some opinions argue that simply mentioning the events in the contract would be enough to qualify the event as force majeure event). In addition, some contracts impose a number of preliminary conditions, involving the notification of the contractual partner (failure to comply with such a notification in a timely manner may result in the interested party losing its right). In order to benefit from the effects of force majeure, it is important for the event qualified as force majeure to occur before the obligation, resulting from the contract concluded between the parties, becomes due or the debtor is already late in performing its obligations. The interested party will also have to request the issuance of a certificate from the Chamber of Commerce and Industry, against a fee.

The performance of the international sales contract, a stage that involves fulfilling the contractual obligations, is transposed into carrying out activities that fall within the scope of international logistics (preparation of goods for deliverypackaging, marking, packaging), organization of transport (pre-transport, international transport, post- transport), insurance of goods in international traffic (conclusion of the insurance policy), completion of customs formalities (for extraEU trade transactions) or related to the financial field (completion of the formalities necessary for the realization/collection of the value for the goods).

The first stage of the organization of logistic activities involves the definition of the logistics solution, i.e. the transport solution and the consequences arising from the chosen transport solution (costs, risks, transit time, etc.).

In the case of global trade in goods, maritime transport holds the largest share, about $80 \%$ of traded goods being transported by sea. The main problem that companies faced during the pandemic was a significant increase in transportation costs, caused by the explosive demand for goods and the global supply chain being disrupted by COVID-19. The coronavirus continues to disrupt global supply chains, blocking ports and delaying ships, all of which limit the number of ships available to transport goods.

The largest increase in transport costs was recorded in container shipping. It currently costs $\$ 14,287$ to transport a container of goods from China to Europe, that being an increase by $500 \%$, and this increase affects the cost of transport for all kinds of goods, from toys to bicycles and coffee. Representatives of the 
associations in the field expect the situation to return to normal as late as the first quarter of 2022.

The Freightos Baltic Index (FBX), a benchmark for the cost of transporting a container of goods on major shipping routes, has tripled in one year, reaching $\$$ $7,000(€ 5,900)$ for a trip from China to the west coast of USA. The cost of a trip to Europe exceeded $\$ 10,000$, as compared to just $\$ 1,600$ in the same period of last year.

Figure 2. Freight Rate Index/ Freightos Baltic Container Index

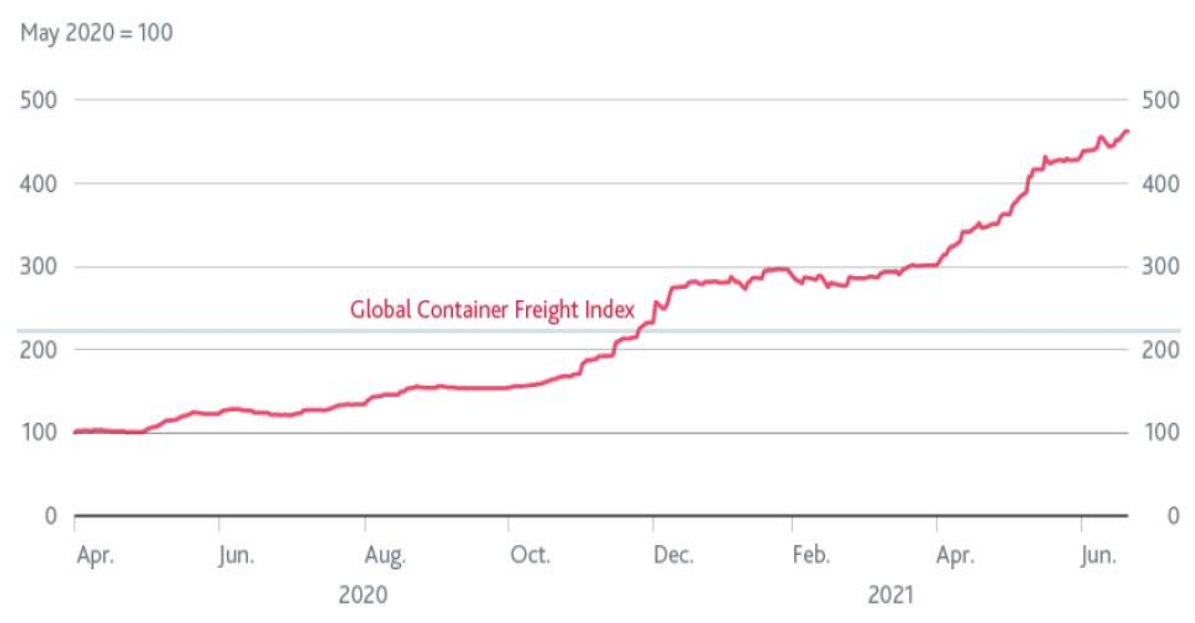

Source: Freighots Baltic Index and Bank of England

As a result of the current situation, some shipping companies have decided to freeze tariffs in order to protect the long-term relationship with customers, i.e. the company has decided to give up part of the profit it could have earned (e.g. CMA CGM).

Other factors that led to increased logistics costs were disruptions in loading and unloading operations, caused by restrictions imposed by COVID, but also by unpredicted events such as the blockage of the Suez Canal in March.

The customs clearance formalities, with a direct impact on transit time, has been directly influenced by the restrictions imposed recently; there were delays in obtaining customs clearance for export/import. In turn, the container crisis also blocked the activity of customs office representatives due to the large volume of goods that were subject to customs clearance procedures. 
Making payments/collecting the value of the delivered goods. The parties pay special attention to the clauses that define the payment solution: the payment method, the payment terms and the payment currency. The parties consider managing risks such as: the default risk (the exporter is the one exposed to this risk), the currency risk (both contracting parties are subject to this type of risk). Regardless of the payment method, the documents play an important role in the payment mechanism and they must be exactly as specified in the sales contract or in the documentary letter of credit. Specifically, each agreed document (commercial, transport, insurance) must comply with the requirements set out in the contract, but also with the conditions stipulated in the letter of credit or the method of payment. Given the importance of documents in the mechanism of the export-import operation, but also the effects of the COVID-19 pandemic on the preparation/obtaining/timely transmission of documents in the course of an export-import transaction, there may be issues related to the collection of the value for the goods or to taking possession of the goods that reached their destination.

\section{The impact of COVID-19 on foreign trade in Romania}

The evolution of the Romanian foreign trade was marked by the direct measures imposed by the pandemic, as well as by the related measures that seriously affected the international trade. In 2020, the volume of trade in goods in Romania was of $€ 142.8$ billion, $8.1 \%$ below the level recorded in 2019 .

The trade balance. In 2020, the differentiated pace of the evolution of export and import led to a significant increase in the trade deficit, of $6.3 \%$ ( $€ 1.1$ billion) as compared to 2019 (from $€ 17.3$ billion to $€ 18.4$ billion). In the period of January-September 2021, the trade deficit was of 16.74 billion euros, i.e. an increase of $€ 3.682$ billion as compared to the same period in 2020 .

Exports amounted to approx. $€ 62$ billion, down by $9.9 \%$ as compared to 2019, having a higher contribution to this reduction. The chart below shows an increase in the volume of goods exported during the period of 2013-2019, the year 2020 being marked by the health crisis. In 2021, according to data published by the INS, exports amounted to $€ 54.53$ billion, an increase by $21.7 \%$ as compared to the same period in 2020 . 
Figure 3. The evolution of Romanian exports

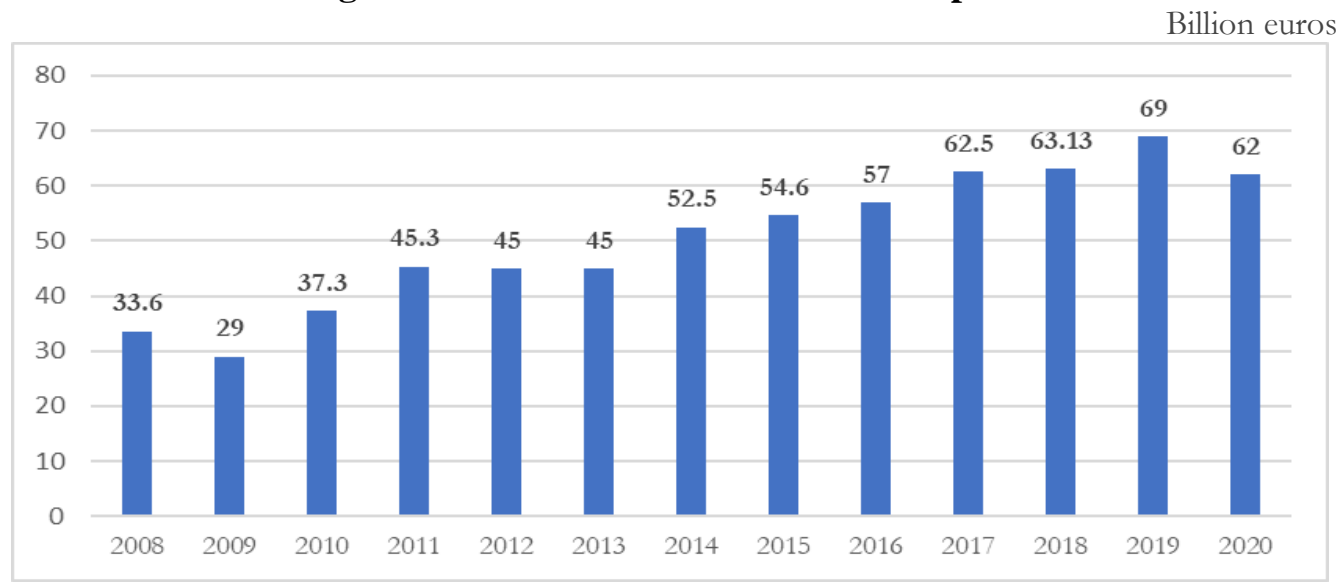

Source: Romanian National Statistics Institute

In terms of exports in 2020, the situation was as follows:

- intra-EU exports amounted to $€ 45.8$ billion, recording a decrease, as compared to 2019 , by $8.9 \%$, and their share in the volume of exports was of $73.6 \%$. We can say that Romania's exports are concentrated on the intracommunity market.

- extra-EU exports amounted to $€ 16.4$ billion, recording a decrease by $12.6 \%$, and their share in the total volume of exports was of $26.4 \%$. As compared to previous years, there has been a reduction in the share of intra-Community deliveries due to the fact that the United Kingdom of Great Britain and Northern Ireland exited the EU.

With regard to the structure of Romanian exports, the most exported products were equipment, materials and accessories for cars, vehicles, clothing and footwear, IT services, food or beverages, as well as many other types of items that contribute - more or less - to a total of $€ 62$ billion in the last year. (see the chart below). 
Figure 4. Structure of Romanian exports in 2020

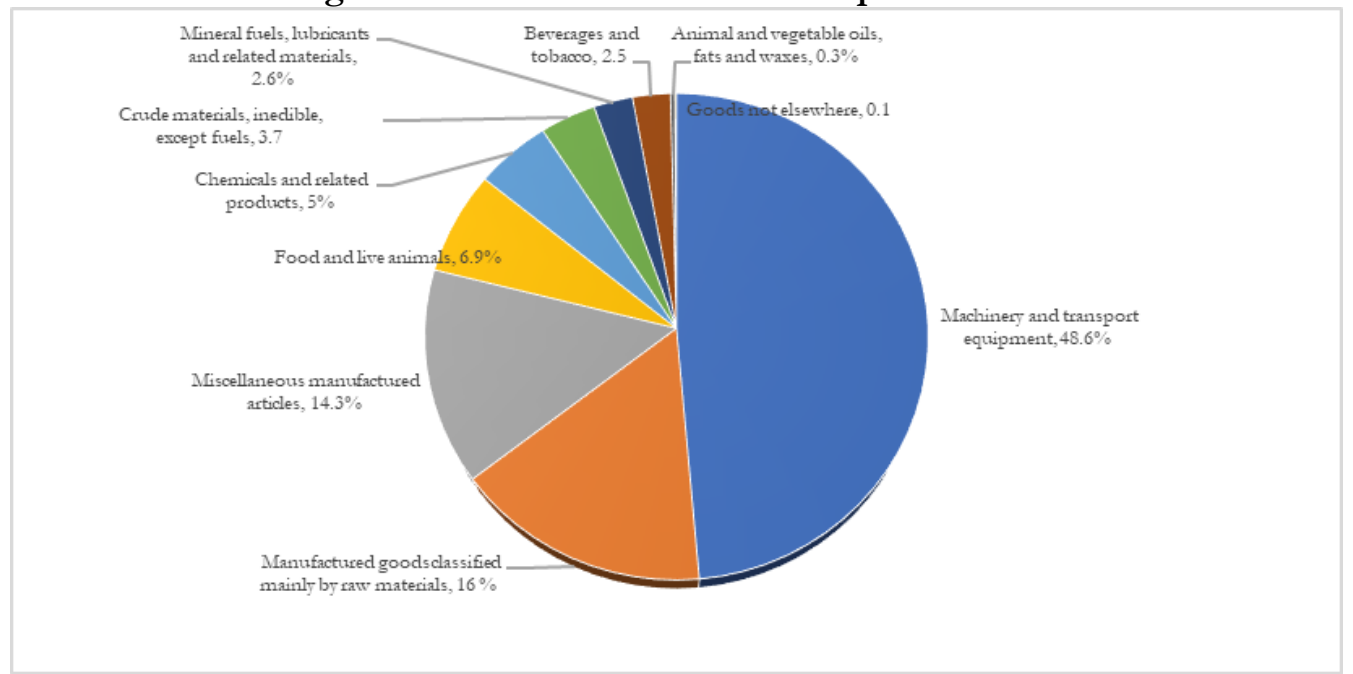

Source: Romanian National Statistics Institute

The geographical orientation of Romanian exports: among the top 10 trading partners of our country, on 30.11.2019 (available data), there are: Germany with a share of $21.71 \%$, Italy $(9.76 \%)$, Hungary $(6.30 \%)$, France $(5.55 \%)$, Poland $(5.11 \%)$, China (4.11\%), Turkey (3.90\%), the Netherlands (3.69\%), Bulgaria (3.34\%) and the Czech Republic (3.10\%), which hold a cumulative share of 2/3 of Romania's foreign trade $(66.6 \%)$.

Figure 5. Main export partners for Romania in 2020

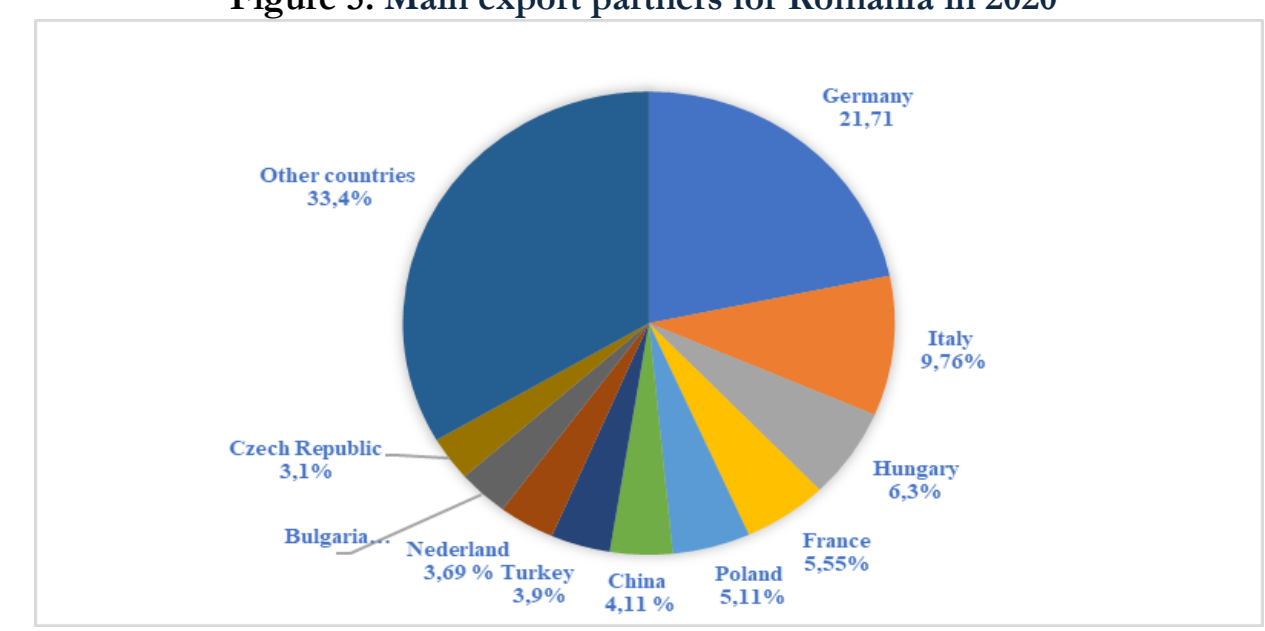

Source: Romanian National Statistics Institute 
Imports had a volume of $€ 80.6$ billion, and recorded a decrease by $6.6 \%$ in 2020 as compared to 2019, due to both the $5.6 \%$ reduction in imports from EU member states (which hold a share of $73.5 \%$ of the total inflows of foreign goods) and the deliveries from the non-EU states that recorded a contraction by $9.5 \%$. In 2021, according to data published by the INS, imports amounted to $€ 71.27$ billion, recording an increase by $23.2 \%$ as compared to the same period in 2020 .

The structure of imports. In terms of the structure of imports in 2020, the share of the "transport machinery and equipment" group was of $37.1 \%$, of the "manufactured goods classified mainly by raw material" group - $18.6 \%$, and of the "chemicals and derived products" group - 14.6\%, the share of the rest of the groups being: "miscellaneous manufactured items" - 11.6\%, "food and livestock" - 8.9\%, "mineral fuels, lubricants and derived materials"- 5.2\%, "raw, inedible materials, excluding fuel"- $2.7 \%$ and "beverages and tobacco"- $0.9 \%$.

The geographical orientation of imports. The top 15 markets of origin of goods entering Romania in the first 11 months of 2020 and their share in total imports are as follows: Germany (20.7\%), Italy (8.9\%), Hungary (7.3\%), China $(6.3 \%)$, Poland (6.2\%), France (4.6\%), Turkey (4.4\%), the Netherlands $(3.9 \%)$, Austria (3.2\%), Bulgaria (3.1\%), the Czech Republic (3.1\%), Belgium (2.5\%), Spain $(2.5 \%)$, Slovakia $(2.3 \%)$ and the Russian Federation (2.2\%). The 15 countries provide more than $4 / 5$ of the total products imported into Romania $(81.2 \%)$.

Figure 6. Main import partners for Romania in 2020

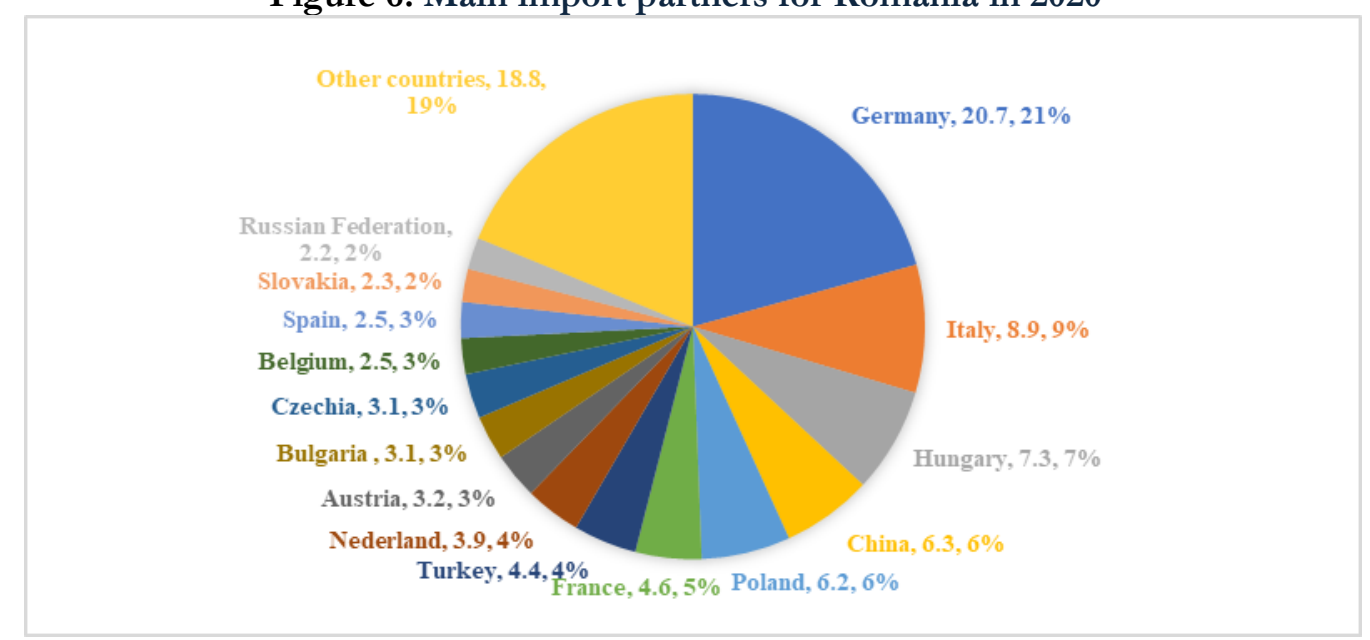

Source: Romanian National Statistics Institute

The charts above show a concentration of exports and imports on the European Union markets. Therefore, the Romanian companies carrying out export-import 
activities are dependent, in proportion of approximately $70 \%$, on the transactions carried out with partners from the EU.

In terms of exports, companies in the automotive industry (car manufacturers and car parts manufacturers) dominate the top 10 places in the ranking of exporting companies. The top ten exporting companies delivered goods and services amounting to approx. $€ 11.85$ billion, accounting for $19.12 \%$ of total exports in 2020 (Roșca, C. 2021). We can say that Romania's exports are dependent on the automotive industry - the share of this sector approaching $40-50 \%$ of total exports.

\section{Conclusions and recommendations}

The COVID 19 crisis has disrupted all activities that contribute to the initiation, negotiation, contracting and conduct of foreign trade operations, having a direct impact on international trade flows.

How can companies overcome the problems related to the management of activities specific to international trade transactions?

The first challenge refers to the reconfiguration of global supply chains: the transition from global supply chains to regional supply chains (from global to regional). In practice, the returning to regional supply chains is a challenge for many companies. By designing a regional supply chain, companies consider, on the one hand, the time required to complete orders and, on the other hand, the criteria related to flexibility and adaptability. The result of the supply chain reconfiguration: contractors, subsystem suppliers and component suppliers will be located in the same area/region.

The configuration of the supply chain is influenced by: the field of activity, the economic and political pressures and the ease of adjustment (replacement of some suppliers and the costs generated by this aspect). By the reconfiguration of the supply chain, companies seek resilience. Supply chain resilience involves, first of all, a quantification of recurrent risks (operational risks) and disruptive risks (risks caused by pandemics, natural disasters, strikes, terrorist attacks).

A second challenge is to diversify export markets and the range of exported products. This diversification is an important factor for the long-term sustainable growth of companies. Market diversification depends on both the capacity of companies and the authorities, who need to identify the most effective tools to support exporters' efforts. Romanian exporters have begun to turn their attention to the traditional 
markets from the past, such as the Middle East, the former Soviet Union, Africa and China.

Finally, the final challenge for companies is to continue the digitization process. Globally, the digital transformation has reduced the costs associated with activities related to international trade, has facilitated the coordination of global value chains and has connected a larger number of international companies and consumers (Belu, M. et al., 2021). Digitization in the field of supply chain of companies involved in international trade is based on the implementation of new technologies such as the Internet of Things, Artificial Intelligence or blockchain. These have enabled the establishment of intelligent logistic operations that have led to reduced inventory costs and to investments redirected towards faster and more reliable deliveries, according to the Just-in-Time principle. Several recent initiatives are assessing the opportunities presented by these new technologies. Optimizing ship speed and routes, for example, can reduce waiting times in ports and CO2 emissions. Port authorities and terminal operators have joined forces to optimize port and intermodal connections. Shippers and other stakeholders have supported a maritime logistics dialogue to encourage data exchange and collaboration across global supply chains.

The main problems related to the supply chain - lack of interoperability, integrity, resilience, transparency - will be the main challenges in a post-COVID world.

An important role in the development of international trade in goods belongs to financial digitization and the digitization of the supply chain, areas in which issues such as security, speed and agility are of predominant importance (Azmeh, Foster, Echavarri, 2017).

In conclusion, we can say that new technologies can be a solution for relaunching international trade. The benefits sustained by digitization are, of course, considerable, leading to efficiency, speed and security in international trade transactions. However, there are a number of challenges and barriers to the development of digital trade and digital platforms, such as the management of data flows and various barriers imposed by different countries, representing directions for action by governments and the bodies facilitating international trade.

\section{References}

Azmeh, S., Foster, C., \& Echavarri, J. (2019). The International Trade Regime and the Quest for Free Digital Trade, International Studies Review, p.2.

Belu, M. (2017). Practica operatiunilor de export-import. Editura ASE 
Belu, M., Dieaconescu. R.I., Paraschiv D.M., Popa, I. (2021). The Impact of Implementing New Technologies in International Trade and Logistics, 7th BASIQ International Conference on New Trends in Sustainable Business and Consumption

Belu, M. (2019). Application of Blockchain in International Trade: An Overview, The Romanian Economic Journal, 22(71), pp. 2-16.

Chopra, S., \& Sodhi, M. S. (2004). Managing risk to avoid supply-chain breakdown. MIT Sloan Management Review, 46, 52-61.

Chudik, A., K. M. Mohaddes, P. Hashem, M. Raissi and A. Rebucci (2020). Economic Consequences of COVID-19: A Counterfactual Multi-Country Analysis, VoxEU, 19 October. Available at: < https://voxeu.org/article/economic-consequencesCOVID-19-multi-country-analysis $>$ [Accessed 15 September 2021]

Dickinson, R., Zemaityte, G. (2021). How has the COVID-19 pandemic affected global trade? Available at: <https://www.weforum.org/agenda/2021/08/ COVID19-pandemic-trade-services-goods $/>$ [Accessed 7 September 2021]

Frydlinger, D., Hart, O., Vitasek, K. (2019). A New Approach to Contracts, Harvard Business Review, September-October

Maryam Al Naimi, Mohd. Nishat Faisal, Rana Sobh \& Lamay Bin Sabir (2021) A systematic mapping review exploring 10 years of research on supply chain resilience and reconfiguration, International Journal of Logistics Research and Applications, DOI: $10.1080 / 13675567.2021 .1893288$

Movius, H. (2020). How to negotiate - Virtually, Harvard Business Review, June

Neil Chueh-An Lee (2021). Reconciling integration and reconfiguration management approaches in the supply chain, International Journal of Production Economics, Volume 242, Available at: <https://doi.org/10.1016/j.ijpe.2021.108288> [Accessed 30 September 2021]

Popa, I. (2006). Negocierea comercială internațională, Editura Economică, București, pp. 126-142

Popa, I., Belu, M. (2018). Afaceri internaționale. Tehnica operatiunilor de export-import, Editura ASE

Roșca, C. (2021). Top 500 cei mai mari exportatori din economie în 2020. De unde vin cele mai mari surprise?, Available at: < https://www.zf.ro/auxiliar/top-500-cei-maimari-exportatori-din-economie-in-2020-de-unde-vin-19962951> [Accessed 2 July 2021]

Shih, W.C. (2020). Global Supply Chains in a Post-Pandemic World, Harvard Business Review, September-October

Shonk, K. (2020). Negotiating Change During the COVID-19 Pandemic, Available at: $<$ https://www.pon.harvard.edu/daily/crisis-negotiations/negotiatingchange-during-the-COVID-19-pandemic/> [Accessed 22 September 2021] 
***, (2021). WTO estimates global merchandise trade volume growth at 10.8\% in 2021 Available at: <https://auto.economictimes.indiatimes.com/news/ industry/wto-estimates-global-merchandise-trade-volume-growth-at-10-8in-2021/86780203>, [Accessed 3 October 2021]

***, (2021). How COVID-19 Has Changed The Trade Show Industry, Available at: < https://www.youngupstarts.com/2021/03/16/how-COVID-19-has-changedthe-trade-show-industry/ $>$ [Accessed 10 September 2021]

World Economic Forum (2020). Mapping TradeTech: Trade in the Fourth Industrial Revolution. [pdf] Brussels: World Economic Forum. Available at: https://www.weforum.org/reports/mapping-tradetech-trade-in-thefourth-industrial-revolution [Accessed 10 October 2021]

***, Rethinking Supply Chain Risk, Harvard Business Review, Available at: $<$ https://hbr.org/sponsored/2021/05/rethinking-supply-chain-risk> [Accessed 10 September 2021] 